\title{
Corporate Social Responsibility for Developing Country Multinational Corporations: Lost War in Pertaining Global Competitiveness?
}

\author{
Philippe Gugler \\ Jacylyn Y.J. Shi
}

\begin{abstract}
This article explores the conceptual and practical gap existing between the developed and developing countries in relation to corporate social responsibility (CSR), or the North-South 'CSR Divide', through the analysis of possible impact on the competitiveness of developing countries' and economies' SMEs and MNEs in globalization. To do so, this article first reviewed the traditional wisdom on the concept of strategic CSR developed in the North and the role that CSR engagement can play in corporate competitiveness, and compare with the impact on the competitive advantage of the South through the supply chains. It points out that among the many factors that could explain the 'CSR Divide', the negative impact of CSR on comparative advantage is the final resort where developing countries are reluctant and defensive toward western-style CSR. It did point out that developing countries are changing their approaches to make CSR work in favor of their competitive position in global trade, such as China who has started to adopt proactive approach by becoming CSR standards-setter. This article concludes with two policy proposals that aim to bridge the CSR gap, the first is to improve CSR standard-setting participation from both sides, and the second to search for solutions in the international
\end{abstract}

Paper presented at the ICCA's Second International Conference "Globalization and the Good Corporation" June 26-28, 2007, Vertical Campus, Baruch College, New York.

Dr. Philippe Gugler is Dean of the Faculty of Economics and Social Sciences at the University of Fribourg (Switzerland).

He holds the Chair of Economic and Social Policy and is Project-leader on investment policies within the NCCR "International Trade" located at the World Trade Institute (WTI) in Berne.

Jacylyn Shi is a Doctoral Fellow at the University of Fribourg and a Research Fellow at the World Trade Institute (WTI) in Berne. investment legal framework which will define corporate obligations in relating to CSR in a more explicit way.

KEY WORDS: CSR, Chinese MNEs, competitiveness

\section{Introduction}

The development of the concept of corporate social responsibility (CSR) has been carried out mainly in the North, from the 1950s when literature focused on responsibility of businessman (Bowen, 1953), to the 1980s when the stakeholder theory took ground (Freeman, 1984), and to the 1990s when more studies on the linkage between CSR and corporate financial performance (Roman et al., 1999). Among a host of benefits arising from being socially responsible, one important argument for addressing CSR is its "business case", in another word, the linkage between CSR and corporate competitiveness (Porter and Kramer, 2006). Despite the absence of an explicit, quantitative translation of socially responsible practices into specific results that affect the profit and loss of a business, there is growing consensus about the correlation between CSR and overall corporate competitiveness (Murillo and Lozano, 2006) and in the linkage between CSR and its impact on national competitiveness (Zedek, 2002).

Comparing to the significant growth in the conceptualization and uprising initiatives being taken in the developed countries, CSR engagement in developing countries in general is lax. The various CSR initiatives that have materialized in recent years in Western countries have not been paralleled by similar intense interest in the context of developing 
countries (Jamali, 2007a, b). However, the CSR discussion traditionally revolved around developedcountry multinational enterprises (MNEs) and their behavior in developing countries has to be reconsidered. Witnessing a "significant share of the investment from the emerging sources of FDI originates from countries that may be characterized by relatively weak legal and regulatory frameworks" (WIR 2006, p. 232), CSR poses great challenges to the developing-country MNEs' aspiration of entering global market, and vice versa, their response to CSR also have great impact on the future global CSR agenda.

This article explores the North-South division through the analysis how corporate responsibility has an increasingly important role to play in leveraging the comparative advantage of the North and the South in the globalization. It starts with examining the traditional wisdom on the role of CSR in building corporate competitiveness at firm level and within the border, it then analyzes the potential roles that CSR could play in the "international competitiveness war" in the North-South matrix ${ }^{1}$ along the supply chains from large MNEs to SMEs, and impact on developing country MNEs who directly seek overseas market. To elaborate on the complexity of North-South divide on CSR and understand the "contextual" element of, instead of a "one-sizefit-all" CSR, the article illustrates how a late-comer to the issue, China is shifting from "defensive" to "proactive" player in CSR engagement. This article concludes by drawing policy implications from the North-South 'CSR divide' for the international community.

\section{Part I: CSR, corporate and national competitiveness}

The mainstream understanding of national competitiveness is often based on the level of productivity of a country which is determined by a set of factors, policies, and institutions (GCR 2006-2007, 2006 , p. 3), ignoring the possibility to ground a nation's economic competitive advantage in the social and environmental performance. Among the 314 indicators used by IMD, corporate responsibility is not part of them. Similarly, the competitiveness index created by World Economic Forum uses the indicators in which CSR is neither a component. $^{2}$

The exclusion of CSR from traditional competitiveness index probably reflected the agency theory as stated by Nobel Prize winner Milton Friedman in the New York Times magazine in 1970, "the business of business is business". This strict view of confining corporate responsibility to ensure shareholder interest excluded the possibility that CSR could be a factor affect corporate competitiveness. After decades of development, a significant departure took place from the emergence of the stakeholder theory, ${ }^{3}$ and the concept and scope of CSR has evolved drastically, from mere philanthropy action to the so-called strategic CSR - to integrate CSR into firms' core business operation through innovation, therefore, enables CSR to be an important part of corporate competitive strategy. ${ }^{4}$ In its Global Competitiveness Report 2005-2006, the World Economic Forum dedicated a chapter on the environment and societal issues as sources of competitive advantage. Even though those thoughts have not be concretized into a formal global competitiveness index, a new paradigm - considering CSR as a source of competitiveness - seems to be accepted in the international institutions, academics and business milieux.

The most well-know pioneer work on linking CSR and competitiveness is Professor Michael Porter's "The Competitive Advantage of Corporate Philanthropy", in which he describes how companies can improve their long-term business potential by linking company's financial goals and its social goals. Porter and Kramer (2003) further postulates that a strategic approach to corporate philanthropy can align both economic and social objectives.

According to Porter, the determinants of competitiveness have two dimensions (Figure 1). The first one is the macroeconomics, political, legal, and social context. This dimension is necessary but not sufficient to generate prosperity. Wealth is actually created in an economy at the microeconomic level, more precisely, in the ability of firms to create valuable goods and services using efficient method. The microeconomic foundations of productivity rest on two interrelated areas: the sophistication and capabilities with which domestic companies or foreign subsidiaries compete, and the quality of the microeconomic business environment in which they operate (Porter, 1990, 1998). The creation of value 


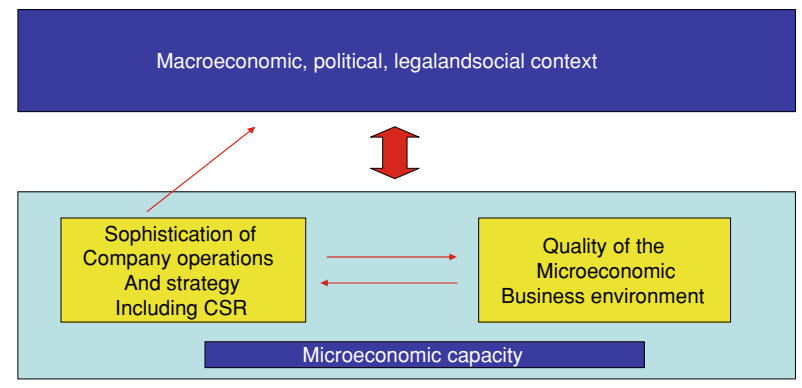

Figure 1. CSR is a factor of competitiveness by acting at three levels. Source: Adapted from Michael Porter, GCR 2006-2007, 2006, p. 53.

in an economy relies on these two microeconomic dimensions: firm's sophistication and strategies, and business environments. Those two microeconomics dimension, in interaction with each other, explain $80 \%$ of the variation of GDP per capita growth across countries (Porter et al., 2006, p. 74).

The Global Competitiveness Report (World Economic Forum, 2006, pp. 51-80) confirms that CSR issues are an important component of firm's sophistications and strategies. As underlined by Davies, "Corporate responsibility is a pact for mutual benefit between society that needs business for economic and social development, and business that needs a supportive business environment" (Davies, 2003, pp. 301-319). Another strong voice in support of granting CSR's "official" position in evaluating economic competitiveness comes from
Swift and Zadek, according to whom the central question is whether and how CSR might impact on and underpin economic competitive advantage in ways that facilitate economic wealth creation and greater social inclusion. Jonathan Low, from Cap Gemini Ernst \& Young demonstrated with his Value Creation Index model that a company's capacity to innovate could be enhanced by CSR through the linkage between reputation and sustainability particularly in higher-income market (Pearce, 2003).

These voices are echoed by many business managers especially from famous world Brands, who advocate for making 'business sense' out of CSR, by integrating the concept into their core business operation. A survey by the Economist Intelligence Unit on "The Importance of Corporate social responsibility" indicated that whereas $54 \%$ of executives in a global survey in 2000 said that the notion of CSR was "central" or "important" to their corporate decision-making, that figure has grown by 2005 to $88 \%$ of executives surveyed (EIU, 2005).

Eventually, driven by the economic interests offered by CSR requirements, i.e., better access to market, finance and business; enhanced intangible assets and reduced risk from regulatory sanction, corporations have to undergo restructuring, innovative processes and technological upgrading that will result in enhanced productivity and efficiency, which will compensate the initial costs and enables its competitiveness sustainable (Figure 2).

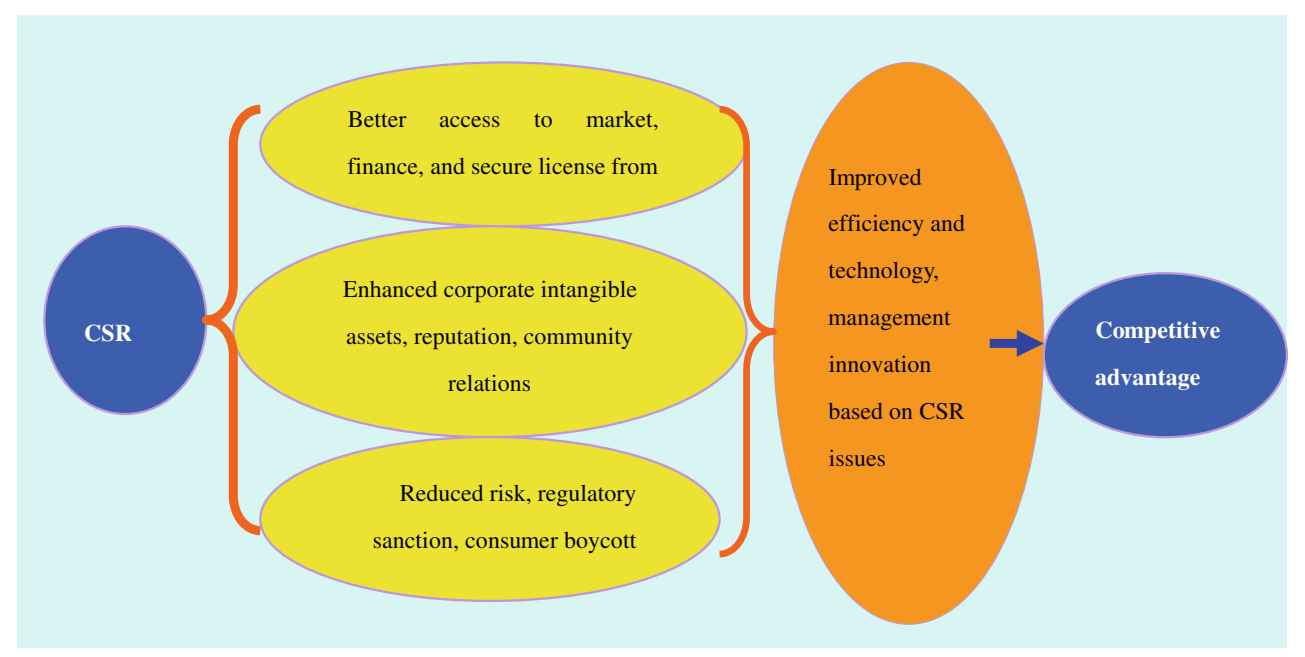

Figure 2. CSR-related elements for corporate competitiveness. 
Impact of CSR on corporate competitiveness through enhanced marketability

Over the past decade, customers are putting more weight on products' social quality than mere technical one. In 2004, Ethical consumerism was worth almost $\$ 44$ billion in the UK. The Millennium Poll on CSR conducted in 1999 found that two thirds of 25,000 consumers surveyed in 23 countries "want companies to go beyond their historical role of making a profit, paying taxes, employing people and obeying all laws; they want companies to contribute to broader societal goals as well., 5

Corporate CSR performance has also become part of the selective criteria to the access to investment and financial market. Morley Fund Management, one of UK's biggest shareholders, has used a sustainability ranking against corporate commitment to social and environmental issues in selecting companies to be included in its pension fund portfolio. Morley said that their decision to publish the list - a first for an SRI fund manager - is part of their attempt to encourage companies to take steps to improve their social and environmental performance. ${ }^{6}$

For suppliers in developing countries, they are increasingly aware that compliance with CSR standards becomes precondition for doing business with MNEs. Otherwise, they could face market sanction, such as consumer boycott in end market, or the multinational companies could simply cancel their contract.

Impact of CSR on corporate competitiveness through reputation

CSR activities are an important component in building reputational capital, ${ }^{7}$ for example, social responsibility is one of the six factors based on which the Reputation Quotient (RQ) was developed by Professor Fombrun and Harris Interactive. ${ }^{8}$ From an economist's perspective, these returns are largely in the future, so the value of a good reputation to a company depends on the number of times and the range of situations it can be used to generate such value (Dowling, 2001, p. 23).

Some businesses doubt the role of reputation for the company's competitiveness, for example, some respondents in the Finnish survey seemed to consider the reputation to have a little or nothing to do with competitiveness (Juholin, 2004). Yet, there is emerging empirical proof of a strong and positive link between reputations and financial performance (Roberts and Dowling, 2002). Malpractice in CSR will cause serious damage to companies' CSR image and financial returns. The case of Nike is a good proof how reputation and financial returns are closely linked. In 1996, its share value plummeted to echo the disclosure that Nike used sweatshop labor in Vietnam. This situation was not able to improve until Nike initiative CSR programs to improve the working conditions. ${ }^{9}$ Strong corporate brands, identities and reputations are increasingly being treated as significant intangible assets, sometimes worth up to twice the book value of their tangible assets (Fombrun and Van Riel, 2003).

Proliferating CSR indices have put company reputation increasingly subject to public scrutiny hence possibility of market sanction (Appendix A). In September 2006, FTSE4Good ${ }^{10}$ announced the addition of 24 companies and the deletion of 9 from its global socially responsible investing (SRI) index series resulting from its semi-annual review (FTSE4Good website). ${ }^{11}$ The deletion exposed the companies and the issues that they failed to address not only to their competitors, but also the investors.

Many governments also join the club by increasingly using CSR information to "name and shame" companies. For example, at the absence of a broad federal CSR mandate, the US government endorses CSR by providing Department of State's Award for Corporate Excellence. On the contrary, in October 2001, the Philippines government developed a listing called the "Poison Award" to publicly identify companies with a poor environmental performance (ENHESA, 2003).

Impact of CSR on corporate competitiveness through regulatory risk mitigation

If reputation plays an important role only in an intangible form, the real teeth of CSR, is the threat of proliferating CSR instruments - "most visible approaches to corporate responsibility today are increasingly formalized and validated through the application of costly standards". These CSR instruments can be voluntary codes of conduct, guidelines, 
principles, voluntary agreements, participation in certification and labeling schemes, however, they are undertaking quiet movement toward de facto mandatory for many firms. Companies in developed countries are under increasing pressure from Mandatory reporting requirements on corporate CSR performance and even legislative reforms to tighten this control (Appendix B).

Impact of CSR on corporate competitiveness through innovation

According to Porter and Kramer, it is through strategic CSR that a firm will make most significant social impact and reap the greatest business benefits (Porter and Kramer, 2006, p. 85); and that a firm will choose a unique position - doing things differently from competitors in a way that lower costs or better serves a particular set of customer needs (Porter and Kramer, 2006, p. 88). In other words, markets are subject to CSR innovation demands, though it may only be in terms of more social responsible productive and less costly manufacturing processes. Brik defines CSR innovation "as the willingness and the capacity to discover, adopt, evaluate and exploit new technologies, products, services or processes for environmental and societal benefit" (Brik, 2007). Many opportunities to pioneer innovations that will benefit both society and firm's own competitiveness can arise in the product offering and the value chain. For example, Toyota's response to concerns over automobile emissions has created Toyota's Prius, voted 2004 Car of the Year by Motor Trend, is the first in a series of innovative car models that have produced environmental benefits and competitive advantage for Toyota (Porter and Kramer, 2006, pp. 88-89).

\section{Part II: "The CSR divide" - CSR in North-South competition}

The above analysis sheds light on how CSR is becoming a strategic force that affects corporation's competitiveness and, therefore, the competitiveness of countries or regions where they are doing busi- nesses. Firms' ability to respond to CSR regulatory pressures becomes an increasingly important factor in maintaining its global competitiveness, since companies are obliged to follow the "international" rules on CSR when they need to acquire 'passport' to the international market. In this case, CSR change the landscape of comparative advantage between the North and South.

\section{CSR in a North-South top-down matrix}

In practice, much of the business activity that has so far been labeled 'CSR' has been driven by the concerns of investors, companies, campaign groups and consumers based in the world's richest countries. The proliferation of various CSR initiatives in the recent decades almost entirely resulted from the North. Stakeholders in developing countries have been object of CSR initiatives rather than active subject in shaping the CSR agenda. There is no wonder that Pascal Lamy, the former EU Commissioner for Trade believes that, inter alia, CSR is to address the "imbalance between the advanced governance systems in industrialized countries, who dispose of a highly sophisticated set of economic and social regulation, and the lack of such governance in developing countries as well as at international level".

For the South, their first "handshaking" with CSR practices is often through the presence of MNEs through establishment of FDI or more directly, through Codes of Conduct developed and imposed by individual buyers from the North (Figure 3). The implementation of the codes by suppliers in the South is motivated by the hope in attracting larger and more stable contracts. As shown in Figure 3, a CSR-friendly company gets "license of operate" in the North has to ensure its supply chain perform in a way free of critics from consumers at home. In China, under pressure from labor rights advocates in their home countries, many multinationals make it an obligatory requirement for suppliers to get international certification. Therefore, the rapid growth in the efforts to develop and establish CSR in the North has strong impact in the South through the strong presence of MNEs. 


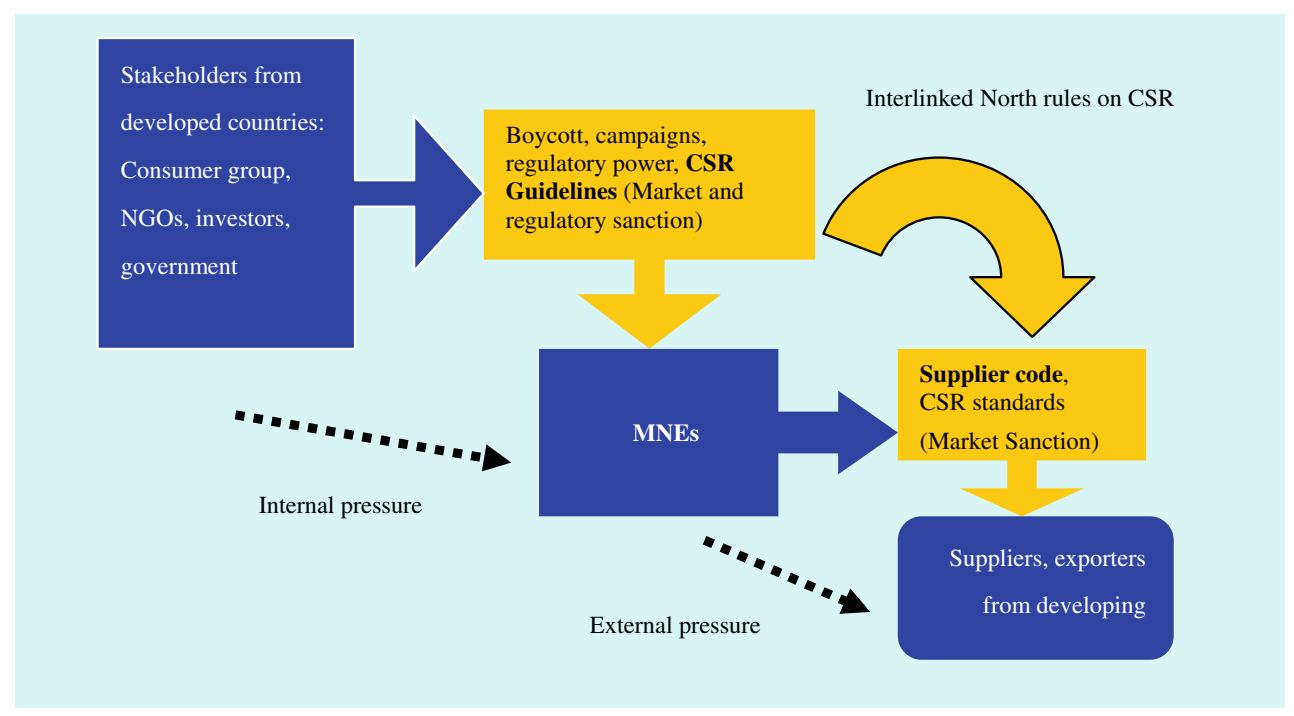

Figure 3. The top-down North-South CSR matrix in global supply chain.

Impact of CSR on competitive advantage between the North and the South

It is commonly agreed that the comparative advantage of the South is mainly based on low cost, one of the crucial cost-minimizing factors being lower social and environment standards. Many MNEs are attempted to chase the lowest standards when these standards vary among countries, aimed at maximizing their short-term competitiveness, the business rationale for multinational companies to establish global supply chain in developing countries. ${ }^{12}$

Under the CSR pressures imposed by different stakeholder groups, especially criticized for their irresponsible sourcing from the South, MNEs from the North responded by establishing private supplier's Code of Conducts usually containing higher standards than what the host country has put in place, and making them mandatory in selecting suppliers. A World Bank survey found that over $80 \%$ of the 107 MNEs surveyed consider the CSR performance of potential partners before entering into business relationship. ${ }^{13}$ This has strong impact on the firms' competitiveness in the South, both SMEs and MNEs.

First of all, CSR could impose potential market access barriers to exporters from the South. "Increasingly stringent requirements for companies to demonstrate their social and environmental policies by adhering to buyers' codes of conduct or private certification schemes have the potential to exclude many southern producers from market access". The detrimental impact on developing country SMEs' export competitiveness was well noted by a UNIDO study, "[small suppliers] may be pressured to rationalize and centralize the supply base, dispensing with the smaller suppliers and denying them access to the export market (UNIDO, 2002)." Where factories cannot do as their buyers asked them, the termination of contracts becomes inevitable. When Gap Inc started to promote 'vendor code of conduct' to its suppliers, it stated "For some manufactures, our standards are too tough. These manufacturers either cannot satisfy our requirements or decide that compliance requires too much time, money and effort. When this occurs, we refuse to do business with them." 14

Thus, CSR accentuates the power imbalance between large MNEs from the North and small suppliers from developing countries. ${ }^{15}$ Many MNEs are driven by the need to mitigate risk to their reputation and simply take short-term approach in dealing with their supply chains by imposing standards without providing financial and technical assistance to the suppliers. Small producers in developing countries have little bargaining power vis-à-vis MNEs, since they risk being squeezed out from the supply chain at the failure of complying with private standards imposed by the buyers. A DESA brief observed this bargaining power disparity 
between producers and buyers, "The experience of business-to-business standards is that costs and benefits tend not to be equitably distributed along the value chains, with costs of private standards borne by producers whereas benefits accrue to the retailer.",16 From the Southern perspective, this created a situation that disadvantages its business due to lack of a level playing ground. An article on Ethical Trading Initiative publication noted that "All this has to be achieved without increasing the suppliers' cost prices, or else they risk losing the contract (Bendady, 2002)." ${ }^{17}$ Moreover, suppliers are often exposed to significant burden of meeting requirements of multiple codes when they work with more than one buyer. Sometimes these codes duplicate or conflict with each other, ${ }^{18}$ and they simply become cost for suppliers to be certified. However, the suppliers are not in a negotiation position with the buyers and can only rely on the information provided by the buyers and subject to the monitoring carried out by these MNEs or a third-party auditor (Twose and Rao, 2003). It is not a rare case that some suppliers are cheating and many suppliers know that their buyers are aware of their non-full compliance.

Secondly, CSR places MNEs from developing economies in a disadvantageous position vis-à-vis their Northern counterpart in global competition.

Adoption of CSR principles is no longer limited to domestic suppliers of developed countries' MNEs, in the light of the increasing of outward FDI from developing economies and emerging markets, "adherence to accepted CSR principles has become so common among global firms that, in order to compete successfully, TNCs from developing and transition economies may also need to adopt similar practices" (WIR 2006, p. 235). MNEs from the South face a more challenging situation when they invest in and source from the North.

Unlike MNEs from the North, which are subject to internal pressure from stakeholders in their home country, the principle source of pressure on MNEs in developing countries become external since stakeholders in developing countries have limited CSR experiences (Figure 4). Therefore, developing-country MNEs are in a less competitive position comparing to their western counterparts, since they are moving toward a market with more stringent rules and "more demanding" stakeholder groups (against Figure 3). MNEs from developed countries share more in common with the society in which they are born, and they have taken proactive approach in establishing voluntary codes based on the general CSR principles and guidelines established by the stakeholders from their home country. As to MNEs from the south, these are exogenous pressures that they might find difficult to match the standards they used to comply with at home.

Comparing with SMEs from the South, MNEs from developing economies are supposedly having better leverage given their business size. However, this depends on whether they are at the buying or the selling end of the supply chain. Both SMEs and

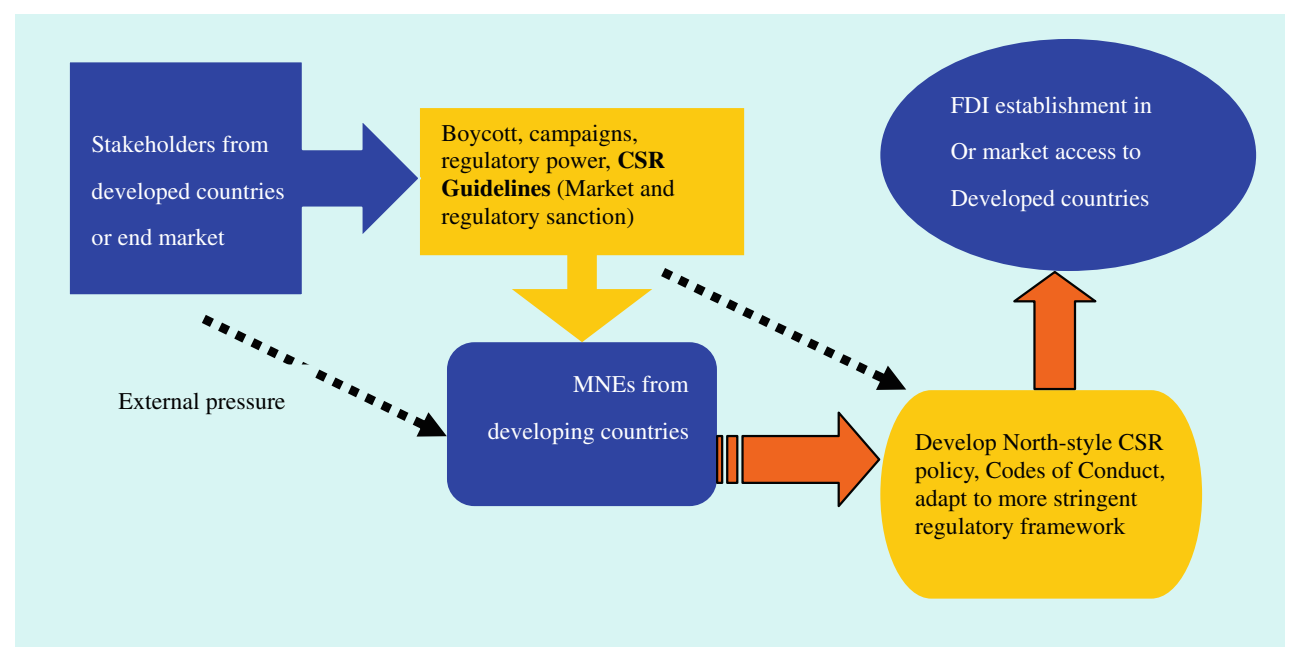

Figure 4. Bottom-up CSR approach for MNEs from developing countries. 
MNEs from developing economies usually base their competitive advantages on cheap components or low production cost no matter where they are located, and the final product will have to be subject to scrutiny of consumer or governmental agencies in the developed countries regarding labor and environmental standards. In the future, it matters how much influence could MNEs from the South exercise on the current and future CSR regulatory environment, which their counterpart in the North has been actively participated in shaping based on their capacities and concerns.

\section{The North-South "CSR divide"}

The North-South divide on the conceptualization and approaches adopted in CSR engagement is evident, nevertheless, it is not all that simple to generalize that the South is a passive implementer or to say the North always presents best example of good corporate citizen.

\section{Different responses to CSR from the North and South} People's attitude toward CSR varies between the North and the South. A survey conducted by a Toronto-based company found out that CSR is more popular in Australia, Canada, the USA and the UK, and least concerns were given in countries like China, Nigeria, the Dominican Republic and Kazakhstan. ${ }^{19}$ A survey conducted by the World Bank $^{20}$ found that companies from Asia and the developing world proved most reluctant to respond to the survey, while companies from the US, Canada, and Western Europe were most willing to participate. The study analyzed that these regions are the home countries where large MNEs based, and regions where CSR issues have received most attention from media and advocacy groups.

Reaction to CSR varies within the group of developing countries, which are different in size, income levels and different export interest, hence different CSR-related concerns. In general, there is pervasive lack of comprehensive understanding of CSR, with limited CSR engagement among developing country enterprises. For example, only $11 \%$ of Indian companies have a written policy although $85 \%$ of the companies agree that they have a responsibility in society (Kumar, 2004). Leading Chinese academia,
Chinese Academy of Social Sciences (CASS) believes that China should not be expected to adopt too high standards, but China should work toward "localized" standards that balance the requirements of international standards while catering to Chinese conditions. As a matter of fact, China is developing an early warning system that will trace the potential threats to Chinese exports including international standards, so that exporters can make due adjustment. ${ }^{21}$

Some developing countries discover that CSR can be a powerful tool to enhance their national competitiveness in the export market. For example, in Viet Nam (Twose and Rao, 2003), in El Salvador or in Malaysia (WIR 2006, p. 237) the Governments see CSR as potential tool to achieve national competitiveness. In Cambodia, learning from the lesson brought by a popular television documentary highlighting the undesirable factory conditions in that country, the government recognized that a CSRbased standards reporting model is a necessary component of Cambodia's export strategy since there is a market niche based on not only price and quality, but also standards. ${ }^{22}$ It also sees CSR a handy tool to enhance its competitiveness against other low-cost producers, especially China, for international buyers looking for "responsible" producers who implement basic labor codes. In Asia, some commented that social responsibility has already made "deep inroads" in reshaping corporate agenda. These are mainly in the corporate philanthropic programs, such as donation to education and healthcare projects by large companies like Sony, Ayala, and Petronas. ${ }^{23}$

MNEs from developing countries are just starting to understand the conception of CSR, often in a philanthropic sense, such as monetary contribution to communities. Their CSR practices are mainly altruistic instead of strategic. For example, out of the 8 large Lebanese companies whose CSR policies being surveyed, only two companies adopt strategic CSR, and they happen to be subsidiaries of western MNEs. "None of the companies systematically measured the impacts of its social investments" (Jamali, 2007a). In the Thai survey (Kraisornsuthasinee and Swierczek, 2006), no informant perceives CSR as approach to achieve higher economic performance. In this case, the environmental and social impacts are not explicitly considered or integrated in their business operations. 
How to explain the "CSR-divide" between the NorthSouth?

The disparities between the north and south are growing, with industrially and technologically more advanced countries and countries at the lower end of economic development. Some believe that it is natural for the north and the south to have different perceptions of and expectations from businesses. ${ }^{24}$

Regulatory gap. For producers in the North, they argue that the imported goods that do not need to meet the same high standards will make their products less competitive due to the gap between the North and South in terms of the level of regulatory stringency, thus, risk a "race to the bottom" phenomenon. Therefore, it is also crucial that producers from the lower end of regulation system also apply the same CSR standards as those at the upper end of regulatory ladder, the MNEs are the channels in enforcing these rules through self-made CSR codes applied through their supply chain.

Many Asian developing countries, including China have quite complete legislations on labor and environment, the standards established sometimes even higher than the international standards. China, Cambodia, Indonesia, Thailand all have clear provisions of laws on maximum working hours, overtime hours, minimum wages. The problem is these laws passed at the national government fail to be properly enforced at local level.

Cultural and value divide. Most firms, as well as the governments from the South often regard the CSR to be largely founded on Anglo-American philosophies and values, and its requirements as an imposed burden by their business partners, therefore, address the issue in a "mock compliance" manner, such as in many Chinese factories (Chan, 2004).

Criticism is heard that standards should not be applied universally to corporate behavior since they are strongly influenced by western cultural values. Some studies try to understand the disparity from the different principles of ethics which result in different understanding toward business conduct in social issues. For example, a study of 210 financial managers from Australia, Chile, Ecuador and the US shows that the Chileans disagree on the bribery definition with the Australians, they also have different ways to look at child labor issues (Robertson et al., 2002).

Even among developed countries, different societies around the world have varying expectations and cultures, and the CSR definition varies depending on the region, its history and development. For example, in Europe, CSR has been used to strategically focus on issues of diversity, employment, and labor relations. However, in the US, CSR has been viewed from the standpoint of corporate governance and market valuation, partly because accounting frauds at Enron, WorldCom and other companies led to the enactment of the Sarbanes-Oxley Act, which aims to reform corporate abuses. As to Japanese companies, they have emphasized more on external environment (Chen and Bouvain, 2007).

Knowledge and information disparity. The knowledge and understanding of CSR between the North and South varies. Most producers in the South focus only on the traditional aspects concerns a product, such as the technical quality, delivery time, and annual certification from local authority. Many large companies from the North have developed over time globally competitive standards of production, marketing and management integrating CSR concerns. The understanding of CSR agenda is relatively limited in developing countries, most businesses believe it suffices to meet the minimal standards set by national regulations in terms of labor conditions and environmental impact and get license to operate from the government. That's why many suppliers feel threatened by the CSR standards suddenly imposed by the MNEs they do business with.

Technology divide. Linking CSR and corporate competitiveness goes beyond mere window-dressing work, it requires strategic CSR that depends on innovative way to enhance efficiency in a socially friendly manner. This can be achieved when a company has sufficient technological resources, R\&D capacity and financial resource. Many MNEs from the North have underwent structural reform and technological upgrading in order to integrate CSR concerns without undermining the need for improving efficiency, however, CSR has not penetrated to the core business strategy of large business in the South. CSR standards established in the North often based on the technological level in the North that the Southern producers find it difficult to adapt to the local context. ${ }^{25}$ Firms from the North, as shown by Kanter, are moving beyond CSR to corporate social innovation. Companies are viewing community needs as opportunities to develop ideas and demonstrate business technologies, find and 
serve new markets, and solve long-standing business problems.

Consumer group divide. In developed countries, the well-established civil society, including media, has an important role to play in promoting CSR to businesses. The stakeholders in the North are more "demanding", and consumers actually exert a tremendous amount of pressure on companies with the help of media, NGOs and trade unions. In the developing countries, the civil society is underdeveloped, whereas more coalitions are taking place to watch corporate behavior, for example, Students and Scholars Against Corporate Misbehaviour (SACOM), the Asia Monitor Resource Center (AMRC), Hong Kong Christian Industrial Committee (HKCIC). Some developing countries are still very cautious about development of civil society in fear of challenging government influence, for example the Institute of Contemporary Observation based in Shen Zhen could not register as an NGO but as a business entity.

Economic-development-level divide. In developing countries, due to limited economic development level, consumer's mindset is different, often concerned with how to increase their income source and alleviate themselves from poverty. For example, a survey conducted in Central and Eastern European countries by the World Bank observed that although the majority of consumers in the region confirm their concern to social and environmental issues, but price and quality of goods are primary factors in their purchasing decision making. ${ }^{26}$

It is not surprising if people perceive the role of business differently between the north and the south, since business cannot operate in isolation from the environment in which they are part of. Many large Asian businesses argue that most US and European MNEs took 200 years to establish their competitive position almost free of challenge, only recently their practices were brought to scrutiny of western civil society. It will dampen the growth of Asian MNEs if Western concept of CSR is enforced. In China, some people argue that it's unfair to subject its business to CSR simply because of its influence in globalization as 'world factory', since its economic level can hardly match those developed countries in the 1990s, when CSR just took off in western societies. Small or even large producers still far away from thinking and acting as modern entrepreneur with global vision due to the given the business environment created collectively. That's why many people hold the opinion that CSR will come naturally when the economic development reaches at a level to be able to afford CSR.

\section{Competitive advantage and CSR divide}

Despite the above reasons, the key resistance voiced by many developing countries is that CSR standards are a mechanism for retaining job and investment in developed countries, since most developing countries tend to compete through lower labor cost and less stringent regulations on corporations. In 1998, the Colombian government representations to the WTO Committee on Trade and Environment and the Committee on Technical Barriers to Trade, setting out its concerns regarding private European eco-labeling schemes for cut flowers and their potential negative impact on Colombian exporters' access to EU market. ${ }^{27}$

Horizontally speaking, cultural, legal, institutional, technological and economic differences would contribute to different attitude and approach in implementing CSR standards between the North and the South. However, this can hardly explain the vertical difference of CSR performance between the head-office of MNE in home country and its subsidiaries often located in developing countries. Transparency International revealed that it's no unique case that MNEs being caught in bribery cases in developing countries, taking last year's Siemens scandal in China as an example. "Among the half million corruption cases investigated in China during the past 10 years, $64 \%$ are directly involved with foreign investors." 29 On August 25, 2006, Daily Business News reported that Hewlett Packard applied double standards to Chinese market that freed itself from environmental obligations. ${ }^{30}$ Even worse, in a list of enterprises that fell below the required environmental conservation criteria published by a Chinese NGO, Institute of Public \& Environment, 33 are well-know Fortune 500 MNEs, including Nestle, 3 M, DuPont, etc., ${ }^{31}$ which are deemed good corporate citizens complying with higher environmental standards at their home countries. This gives more grounds for developing countries to be skeptical about the 'genuine concern' of large MNEs in imposing high CSR standards to the developing country suppliers. 


\section{Part III: CSR in China and its implications for Chinese MNEs' competitiveness}

As the world's fourth largest economy and largest developing economy, China's foreign trade sectors, which accounted for 65\% of national GDP in 2004, cannot afford to overlook the sweeping impact of CSR on business decisions made by MNEs. China's outstanding export performance in the past two decades has closely associated with manufacturing goods, mostly labor-intensive, which amounts to over $90 \%$ of China's total exports (Zhang, 2006b). ${ }^{32}$ Therefore, the Chinese business and government have been taking skeptical attitudes toward CSR activities carried out by foreign MNEs, especially when their labor-focus clearly threatens the country's comparative advantage in international trade. ${ }^{33}$

\section{CSR development in China}

The CSR movement was introduced into China in the mid-1990s, when brand names started to impose various supplier codes of conduct to the textiles and garment factories under the pressure from antisweatshop activities abroad (Chan and Ross, 2003). China's CSR development illustrates two opposite forces, drastically increasing profile of CSR on one hand and continuous strong resistance on the other (Table I).
Reluctant to follow suit in addressing social issues related to business operation the same way the westerners do, the Chinese leadership emphasizes sustainability policies in other terms at macro-level, such as promise to the world that by 2020 it will quadruple its economic growth while only doubling its energy use; and domestically, the government advocates for a new concept of "creating a harmonious society (he xie she hui)" which embodies the idea of encouraging businesses contribute to sustainable social and economic development. ${ }^{34}$ In 2004, the Chinese government announced a new green measurement of GDP taking into account the wider social and environmental costs of China's economic growth, ${ }^{35}$ demonstrating China's willingness to catch up with sustainable development policies.

Among businesses, most Chinese companies are actually just getting started with a learning process on CSR initiatives, but CSR takes ground in China expeditiously, in particular among managers of export-oriented factories. Many large-sized enterprises recognize an increasingly active CSR engagement will offer them a chance to become globally competitive, for example, participation in the Global Compact. However, it's important to note that Chinese companies are expecting shortterm business interest in participating in CSR initiatives, and largely motivated by the benefits of securing contracts from international buyers. Half

\section{TABLE I}

Evolution of CSR in China

Phase 1 (1996-2000)

Multinational companies started to impose supplier codes and began auditing Chinese factories. At this stage, CSR is still a new concept to many Chinese. Chinese government, public, media and domestic Chinese enterprises had limited awareness of the topic. Media coverage of CSR is also scarce.

Phase 2 (2000-2004)

The CSR movement was pushed by international organizations and NGOs. Chinese suppliers recognized the increasing pressure from excessive auditing and CSR compliance requirements. Several government departments, Ministry of Labor, the Ministry of Commerce and the Chinese Enterprise Confederation all set up CSR committees to investigate if international organizations and MNEs are applying labor conditions as barrier to trade. The government chose to adopt a "wait-and-see" approach toward CSR activities.

Phase 3 (2004 - today)

CSR became a buzz word across enterprises and went beyond export processing companies to domestic and state-owned enterprises. Chinese government silently shifted from a passive approach to active participation, such as creating home grown CSR standards to maintain Chinese corporate competitiveness in global market.

Source: Adapted from “Will CSR work in China?” Zhou, W. D. Business for Social Responsibility. Summer 2006. 
of the Chinese participants of the Global Compact are "inactive".

CSR engagement presents a geographical disparity in China due to level of economic development and sectoral focus. The most advanced region in terms of CSR awareness and engagement is evidently the South China Guangdong province, which accounted for one-third of nation's total exports ${ }^{36}$ and where most foreign invested enterprises are based (Zhang, 2006b). ${ }^{37}$

China's CSR engagement has not yielded any systematic approach so far, and the notion of sustainable development is still a new concept to many business managers. Most companies taking philanthropy as substitute of CSR, and others hold a "wait and see" attitude for government regulatory pressures.

\section{What does CSR imply to MNEs from China?}

Supported by the government policies of "going global" and of creating 30-50 internationally competitive "global champions" firms, an increasing number of Chinese firms are now among the largest MNES from developing countries, in terms of foreign assets: in 1994, only 7 Chinese enterprises were among the top 50 largest MNEs from developing countries; by 2001, 12 MNEs were in the top 50, and 6 of them had foreign assets of above $\$ 2$ billion. $^{38}$

Chinese MNEs are picking up a fast-track learning process of CSR. Till 2004, Haier was the only Chinese brand recognized in the Global Name Brand List edited by World Brand Laboratory, one of five world brand evaluation agencies. ${ }^{39}$ Its brand building in the 1980s focused on technical qualities and in the 1990s on innovation. During its "globalization" process in which Haier expanded its manufacturing bases overseas, it clearly experienced the pressure from environmental regulation and safety standards. Green marketing and consumption now dominates the senior management's agenda, for example, in the R\&D of central air conditioner products, Haier prioritizes "energy saving and health" as two major themes. Its senior management has developed new concept of running business that emphasizes contribution that Haier should make to the society, their focus has changed from the 1980s'
"Flawed products are nothing but a waste" to today's "Haier will become an integral part of the society" (Wang and Kang, 2002).

Other large Chinese enterprises who took longer to learn about CSR paid their price. China Mobile, the 5th among the 22 Fortune 500 telecommunication companies in 2006 in terms of profit, was only the 15th in the list of "most respected enterprises". In the 2006 CSR evaluation published by the Fortune Magazine, China National Petroleum Corporation and China National Grid were even among the bottom two. ${ }^{40}$

Recent years, Chinese overseas investment encountered frequent setbacks due to negligence of CSR issues. In Peru, June 2006, local workers at China's Shougang Group (Steel Group) investment in Peru (Shougang Hierro Peru) continued a 3-week strike demanding for pay raise. The strike was called off until Chinese investors agreed to raise salary required by the Peruvian authority. ${ }^{41}$ In Zambia' Chambishi copper Mine, Chinese investors were accused of non-compliance with labor standards and undesirable working conditions. Six workers were hurt by gunshot in the strike. ${ }^{42}$

The Economic Weekly of the People's Daily conducted a comparative analysis between China's 500 strong enterprises with those of the world. It pointed out the threat to China's long-term competitiveness that China's high-speed economic growth has been done at a big price of resources and environment. "In 2003, the per unit GDP consumption of energy resources was 10 times that of Japan, 5 times of the USA and 3 times of Canada, and the metal consumption was 2-4 times that of the world average." 43

UNCTAD survey found the main driving force for Chinese MNEs' internationalization is "the need to bypass trade barriers" and "the need to utilize domestic production capacity" because the home market for their products is too small, are key drivers of internationalization. (WIR 2006, p. 156). The future "Chinese giants" will unavoidably encounter the CSR challenges when they move to a market with higher social standards, as demonstrated in Part II: 2 in this article, and what left to Chinese MNEs, and other developing-country MNEs, is to find out how to apply CSR to enhance their visibility and marketability through intangible assets building and technology and management innova- 
tion, or they can risk of being perceived as exploitative and CSR-unfriendly.

Future of CSR in China - from standards-taker to standards-setter?

The businesses in China start to call upon a Chinesestyle mechanism similar to those imposed on them developed overseas, which takes into consideration the real situation in China and based on Chinese laws and regulations that protect workers' rights and other social concerns arisen from business operation.

In terms of labor standards, China decided to limit and monitor certification to international CSR and labor standards. In November 2004, the Certification and Accreditation Administration of China (CNCA), the Chinese government's certification authority, announced that, among others things, no social responsibility certification, such as to Social Accountability (SA) 8000 may be conducted without approval from CNCA. It also stated the ISO Social Responsibility guidance standard being developed, and in which China is participating, should not be used for auditing or certification purposes.

At the same time, China announced that the China State Standardization Management Commission will investigate the feasibility of a domestic Chinese CSR standard. Until that research is completed, foreign companies that have obtained international labor and environmental certifications in China must report them to the CNCA.

In May 2005, China introduced a homegrown audit of the textile industry to certify company compliance with minimum working conditions, China Social Compliance 9000 for Textile \& Apparel Industry (CSC9000T). The joint initiative by the Responsible Supply Chain Association and the China National Textile and Apparel Council was also responding to the need of easing trade friction with key trading partners such as the United States, and sorting out differences over employment practices, and issues such as US quotas on Chinese exports. Before CSC9000T, China had no standard to certify that a factory complies with Chinese labor laws, and compliance with labor standards in China has been driven mainly by international standards imposed by multinationals such as Wal-Mart and Nike.
In November, 2006, China launched another homemade CSR standard that is applicable to all sectors, China CSR Management System (CCSC) Guidelines and Provisions. CCSC established detailed regulations in five areas: labor protection, credit, environment protection, social charity and product quality. ${ }^{44}$

In March, 2007, "Management Methods for Controlling Pollution by Electronic Information Products", known as Chinese RoHS came into effect. For the semiconductor supply chain, this poses another big challenge following the launch of European Union's 'Restriction on Hazardous Substances' (RoHS) in 2006 that directive re-ignite the concerns and debates on labeling requirements, exemption questions, material declaration and compliance processes. ${ }^{45}$ Bearing the same scope of hazardous substances to be controlled, the Chinese regulation is different from the EU RoHS in many ways. ${ }^{46}$ For supply chain, this means that they have the uncertainty if their products will be covered by the Chinese RoHS or not, and they have to be cautious to meet requirements of EU RoHS once they are, such as pre-market certification labels.

In the past, Chinese companies have traditionally active in obtaining international standards, which used to concern technical requirements, such as ISO 9001. Among the 500,000 firms accredited by ISO 9001, 130,000 are in China. There is no doubt that these firms continue to participate in new standards established by this accredited organization, such as the ISO 260000 on CSR standards. However, the fundamental question is how the Chinese businesses can integrate the concept of CSR into long-term business management if their business perspective is based on short-term gain.

\section{Part IV: Policy recommendations and conclusion}

According to Dunning, responsible global capitalism is a system containing a number of parts, and all parts must work closely together if this system is to be effective. The main players in this system are MNEs, non governmental organization (NGO), governments, and supra-national agencies such as the World Bank and the International Monetary Fund (IMF) (Dunning, 2003). China's CSR case 
further proves that no black-or-white simplistic view should be adopted if the international community, i.e., the above stakeholders wishes to bridge the CSR divide between the North and the South, and to develop a common language and policy framework to optimize business' contribution to society.

Full participation of CSR standard setting

from both North and South

The majority of CSR standards are now developed by large MNEs from the North, based on the social and environment conditions of their home countries. The focus of issues and standards reflect the concerns and priorities of consumers in the North regardless of the relevance or importance of those issues in developing countries (Blowfield, 2000). The governments or firms from the South have limited participation in the "rule-making" process, such as the development of ISO $26000 .{ }^{47}$ The current situation ignores the reality that CSR practices are diverse and reflective of the national, regional as well as local context, based on variance in legal regimes, institutional structure, social and cultural attitudes, natural endowment of production factors and environment conditions. A well-known example is the EU Ecolabelling Regulation criteria that concerns only energy efficiency without taking into account the renewable energy sources which are important for some developing countries, for example, biofuel for producers in Brazil. Unless countries from both the North and South fully participate in the standards making process, these standards can be truly valid with adequate ground for enforcement.

The top-down approach of CSR strategies along the supply chain damages suppliers' competitive advantage, therefore, is not achieving improved CSR implementation and is not sustainable. By the end of the day, the emergence of CSR in the "competitiveness war" risks of being materialized into a race of CSR standards creation, which will reduce the efficiency of whole society given the costs spent in complying with a proliferated network of CSR measures which may entail either duplicating, or inconsistent even contradictory requirements.
Consensus will be difficult to reach, however, the South has to actively participate in CSR standards and policy making process among both businesses and regulators, and at international level through collaboration between national governments, or through multilateral approach with participation of various stakeholders. This requires the cooperation from the North, which should be responsible in managing the cost and risk of CSR initiatives between businesses along the supply chain.

For developing country governments, CSR poses challenges to national policies. It can be used as a leverage, to the favor of improving competitiveness, or erode competitiveness. If CSR codes imposed by MNEs can lead to exclusion of domestic suppliers, especially SMEs from the international supply chain, there is a clear rationale for government intervention in a number of ways. The government should actively adopt labor standards performance and reporting criteria for the granting of government loans, grants, overseas investment insurance, or other benefits tied to overseas investment by developing country companies. In a highly competitive market, companies that take the steps necessary to truly address labor and human rights issues find themselves undermined by less scrupulous competitors. If the governments can work together to establish common standards and rules that takes into account of CSR issues that all business should comply with, large corporations find little chance to accentuate the imbalance by playing the power and resource disparities intrinsically attached to large MNEs and small firms, and mitigate the less competitive positions of MNEs from the South being late comer to the field.

At international level, concerned international organizations should take into consideration the impact of CSR on country's international competitiveness and seek solutions to create a level playing ground for the pioneer members and late comers to the CSR topic. One possibility is to integrate CSR into international investment legal framework.

Integrate CSR into international investment legal framework

The legal rationale of including CSR in international investment agreements (IIAs) is based on the rec- 
ognition of private parties (businesses) as subject to substantive rights, not only procedural rights in international law. The full recognition was given by granting them access to international dispute settlement. Thus, the effectiveness of the substantive and procedural rights accorded to private parties is truly guaranteed by strengthened enforceability. There is a necessity to balance by increasing the weight of corporate obligations in the agreement where their rights enjoy full protection. In this context, we need to redefine the scope of CSR to fit in the investment law context. What are the possible scenarios of incorporating CSR in int'l investment agreements in the future?

Inclusion of CSR in existing investment agreements? At the absence of a multilateral investment framework, bilateral investment treaties (BITs) take the leading role in defining investor-state relationship and their rights and obligations. BITs demonstrate similar pattern among them in emphasizing the protection of investor rights and limiting host country's regulatory authority. It has also become increasingly common for BITs to provide investors access to dispute arbitration with state, to ensure the enforceability of IIAs in protecting investor rights. BITs are typically free from including other international treaties signed by the contracting parties in the area of human rights, a crucial part relating to corporate responsibility; nor do they condition investor rights upon responsibilities of the investor in these areas such as respect of human rights in its operations, labor, health, safety and environment protection. Besides, BITs do not link investor's rights to access to dispute settlement with investor's obligation in CSR issues - this is the missing block in the investment agreements, which is attracting mounting interest in building a more balanced investor-state relationship in IIAs (Table II).

\section{Inclusion of CSR in a future international agreement on investment?}

There has been much debate in recent years over the desirability of an international agreement on FDI since the current framework is characterized by a "spaghetti bowl" comprising around 2,500 Bilateral Investment Treaties (BITs), some 200 regional cooperation arrangements, and some 500 multilateral conventions and instruments governing cross- border investment flows (Gugler, 2006). While some experts argue that such an agreement is unnecessary because the market will discipline errant states and firms, others are of the view that an overarching agreement on investment would reduce the conflicts among states and MNEs (Goulborne, 2003 , p. 10). One of the most important initiatives to create an international investment framework has been the Multilateral Agreement on Investment (MAI) negotiated at the OECD and proposed in 1995. The MAI was intended to provide a multilateral regime for FDI with high standards for the liberalization of domestic investment regimes, the protection of investment and effective dispute settlement mechanisms. The MAI failed due to important oppositions. Some countries argued that the OECD was the wrong venue for negotiations because it did not include developing countries in the discussion. Furthermore, labor and environmentalist groups were of the view that the MAI would allow MNEs to disregard workers' rights and pollute the environment (Brunner and Folly, 2007).

There are legal problems to be considered with the above proposals. Investor obligations are qualitatively different from host state rights or obligations. An international agreement, signed among sovereignty states, will find it problematic to seek specific obligations of private party. However, it is not new that specific individual obligations start to be included in some human rights laws, which creates rights for individuals at first place. IIAs, creating rights for investors by subjecting the conduct of states to investor-state arbitration, why not take the next step and seek to create obligations for foreign investors.

\section{Conclusions}

CSR issues are likely to become more important as firms in developing and transition economies expand abroad. Discussions on CSR that have been traditionally revolved around developed-countries' MNEs and their behavior in developing countries need to be expanded. As underlined by UNCTAD, the MNEs from developing and transition economies are already and will be more and more exposed to similar issues: "While adherence to various internationally adopted CSR standards may entail costs for the companies concerned, it can also gen- 


\section{TABLE II}

UNCTAD proposals on how to include CSR in investment agreements

Option 1: No reference to CSR, which is now the case with most BITs, but some indirect coverage

- Foreign and domestic investors are equally subject to the social and environmental responsibility requirements of the host country.

- The investment agreement can contain a reference that entry of investors and investments should be done in accordance with laws and regulations of the host country

Option 2: Non-binding CSR standards included in the agreement

Option 3: Reservation of regulatory powers on issues of social and environmental responsibility

- Option 3.1: The investment agreement allows the exclusion or exemption from investor protection in order to permit host countries to regulate investors and investment from a CSR perspective, for example by using an exemptions list in the investment agreement.

- Option 3.2: Inclusion of an article in the investment agreement that allows countries to adopt laws and measures, provided they are not discriminatory or arbitrary, that protect for instance human and animal health and life, public morals and treasures, exhaustible natural resources, sufficient supply to the population or domestic industry (see WTO: Art. XX of GATT1994).

Option 4: No lowering of standards clause

- Inclusion in the investment agreement of an article that ensures that host countries can introduce or maintain environmental or social regulations that also apply to foreign investments or investors (see NAFTA art. 1114).

- An article in the investment agreements states that governments should not attract particular investments by relaxing standards on the environment, consumer protection, core labour standards, and human rights.

Option 5: Home country measures to promote CSR

- Option 5.1: A non-binding obligation to ensure the "best efforts" of the home country to encourage CSR behavior by its investors, for example by encouraging investors to adhere to the OECD Guidelines

- Option 5.2: A binding commitment is made under the investment agreement by home countries to supervise the CSR behavior of its companies abroad.

Option 6: Inclusion of a generally binding CSR provisions in the agreement

- Option 6.1: Inclusion of binding articles on CSR provisions.

- Option 6.2: Annexing existing CSR instruments or international agreements as binding provisions.

- Options 6.3: Linking the investment agreement with a range of agreements and codes by encouraging the parties to the investment agreement to sign up to these agreements and codes.

Source: UNCTAD, International Investment Agreements - Key issues, Vol. II, 2004, pp. 129-151 (summarized by M. Vander Stichele, SOMO Discussion Paper 1, 2005).

erate important advantages, not only for the host country but also for the investing firms and their home economies" (WIR 2006, p. 240). In light of above, understanding the paramount concern about developing-country corporations', especially the emerging MNEs' international competitiveness in relating to CSR, as illustrated in this article, is the first step toward a long process of bridging the conceptual and practical gap, in another word, the North- South CSR division. What lays before the international community, in particular the legal communities is the task of searching for a feasible framework that could create a level playing ground for all players from both sides, and stop the vicious circle of "race to the bottom". It should be avoided that CSR be applied merely as a market-driven mechanism and as an effective tool in leveraging the competitive advantage, to ensure the linkage between CSR and competitiveness needs to be established from an expanded view on the linkage between CSR initiatives and the assessment of their actual impact on social and environmental issues.

\section{Notes}

1 Even though social clause also pertains to SouthSouth trade relations and competition, this article mainly focuses on the North-South dimension.

2 Comparing with the traditional robust competitiveness indicators, CSR is sometimes regarded as a "back- 
up" element. One comment made by Steven Bennett, leader of an NGO from Cambodia, Global Fairness Initiative illustrated the conditionality when CSR works as a determinant factor for competitiveness - "when all things being equal, if a country can produce garments at a competitive price, at a competitive speed and a competitive level of quality, then labor rights verification becomes a very significant factor in garment sourcing decisions by big companies, such as Gap, Nike, H\&M and Levi Strauss". World Bank online discussion: http:// rru.worldbank.org/Discussions/Discussion.aspx?id=72.

3 The agency theory and stakeholder theory are not mutually exclusive. Shareholders sometimes count as part of stakeholder of a firm and vice versa.

4 In this case, companies' acceptance to CSR does not necessarily conflict with Friedman's statement only when companies are able to make business sense out of CSR, can they sustain their responsible behavior toward environmental protection and good labor practices.

5 The survey was jointly carried out by Environics International Ltd and Prince of Wales Business Leaders Forum. For executive briefing, please see http://www. iblf.org/docs/MillenniumPoll.pdf.

6 The companies heading the list with the best overall performance were AstraZeneca, GlaxoSmithKline, Pearson, Smith \& Nephew and Reed International. At the bottom were British American Tobacco, Enterprise Oil, Rolls-Royce, BAE Systems, Gallaher and Imperial Tobacco. Visit city of London website: http://www. cityoflondon.gov.uk/Corporation/living_environment/ sustainability/awards_morley_fund_management.htm.

7 Reputational capital is often defined as the difference between the book value of an organization and its market valuation.

8 Gillian Cribbs, G. 2003. How can you put a value on reputation? Corporate Image: most companies acknowledge the importance of their good name. Financial Times, London, Nov. 20.

9 Anti-Nike campaigns started 1988 when poor working conditions in Nike's Indonesian factories were exposed. Since then, anti-Nike has been central to the entire 'anti-sweatshop' movement globally.

10 FTSE4Good is an index for socially responsible investment designed by FTSE, composed of a series of benchmark and tradable indices facilitating investment in companies with good records of corporate social responsibility. FTSE4Good criteria aims at promoting incremental progress in CSR performance, and climate change is the latest topic covered in newly proposed standards. http://www.ftse4good.com/frm_home.asp.

11 Deletions included Enel for acquiring a nuclear power producer, Hasbro for falling short on supply chain labor standards, and Harley-Davidson and six others for failing to meet environmental criteria.

12 As EU Trade Commissioner Mandelson put it, low-cost is the key to European businesses' competitiveness: "Europe's markets must be open to cheap supplies of intermediary goods and raw materials for European producers of value-added products. Restricting this flow of goods raises costs for European companies, making them less competitive. We need to import as to export."

13 World Bank (2003).

14 See "Beyond the Label: Gap INC's Commitment to Ethical Sourcing", at http://sparky.harvard.edu/ m-rcbg/hiv-aids/Beyond_the_Label.pdf.

15 There are now approximately 64,000 MNEs defined as firms that engage in international production - with over 870,000 foreign affiliates. Taking Nike as an example, it has more than 800 subcontractors in 50 countries around the world, employing more than 600,000 workers.

16 Sustainable Development Innovation Briefs. United Nations Department of Economic and Social Affairs, February 2007.

17 For example, the certification SA8000 will cost a firm with 1,500 workers US $\$ 27,000$ for a first-time accreditation. This does not include the adjustment cost in complying with the SA8000 standards.

18 Convergence of codes has taken place only in limited number of sectors, for example, the Electronics Industry Code of Conduct created in 2004 through the collaboration of eight companies has undertaken extensive benchmarking process aimed to achieve a more harmonized approach to workplace standards.

19 "Millennium Poll on Corporate Social Responsibility", Environics International Ltd. 1999.

20 Race to the Top. World Bank and IFC Project. 2003.

21 More details please visit China National Standards Consultation website: http://www.chinagb.org.

22 International Finance Corporation and World Bank (2005) Cambodia CSR In the Apparel Sector and Potential Implications for Other Industry Sectors.

23 Life lessons for big business". South China Morning Post, Hong Kong, Oct. 21, 2002.

24 Amaeshi, K. World Bank Institute learning program. http://info.worldbank.org/etools/docs/library/ 57481/northsouth_finalist.pdf.

25 An example is the energy and pesticide level required by the Dutch flower industry does not take into account the need for artificial lighting necessary in Kenya cut-flower production.

26 Will Responsible Business Increase the Competitiveness of Developing Countries? Online discussion 
organized by the World Bank (2006). http://rru. worldbank.org/discussions.

27 More details see World Trade Organization Committee on Trade and Environment (CTE): http://www. wto.org/english/tratop_e/envir_e/wrk_committee_e.htm. 28 Richard Milne. Siemens bribery scandal raises further questions. Financial Times, December 21, 2006.

29 News Xin Hua. December 6, 2006. Rethinking Simens' Bribery Case, Experts Call On Anti-Bribery Law. http://news.xinhuanet.com/lianzheng/2006-12/ 06/content_5444650.htm.

30 Business News Daily. Recycle Printer Parts as "Environment Show" in China, August 25, 2006.

31 Institute of Public \& Environment, http://www. ipe.org.cn/bdbqy/index.jsp.

32 According to the World Competitiveness Report (IMD, 2006), China's main strength lies in its large labor force and the size of its domestic market. China's abundant labor force, are willing to work for a fraction of the wage in developed countries, and also beats out other emerging economies such as Brazil and India. Meanwhile, Chinese exports in traveling goods, toys, sporting goods, footwear and non-textile clothing accounted for over $20 \%$ of total world exports.

33 Some Chinese officials argued that as a socialist country as China cared for its workers and resented outside interference. "The Chinese communist government didn't want to be taught by foreign capitalists how to treat workers," a top official complained, http://www. europeanchamber.com.cn/show/details.php?id=512.

34 More information please refer to China harmonious society website: http://www.chinahexie.org.

35 China Releases Green GDP Index, Tests New Development Path, http://www.worldwatch.org/node/ 4626.

36 Ministry of Commerce, China (2004).

37 For example, Starting 2003, Shen Zhen government has attached serious attention to the impact of expanding influence of CSR movement. The Municipal Labor Bureau committed a report to the Shen Zhen Government entitled "Shen Zhen Should Urge Companies to Fulfill Their Social Responsibilities". Consequently, the Shen Zhen government is mandated to establish and advance a CSR policy, a key item on its 2006 agenda (Zhang, 2006a).

38 UNCTAD FDI Statistics, http://www.unctad.org/ Templates/Page.asp?intItemID $=3135$.

39 WTO Guide. Haier Group: Assuming Social Responsibilities and Building Global Brand. Nov. 2005. http://www.wtoguide.net/html/2005Sino-European/14_ 29_15_399_4.html.

40 China Mobile announced in January this year to improve CSR, an indispensable "soft criteria" that deci- des their sustainability in the global competition, and it became the first telecomm company in China who issued a CSR report. China National Grid thereafter declared to work on publishing annual CSR report and make it part of its corporate strategy (China Management Newspaper, January 14, 2007).

41 Sina News network Finance, August 17, 2006, http://finance.sina.com.cn/money/future/20060817/14 102831493.shtml.

42 Anbound Economic Daily, August 15, 2006, http://www.szsti.net/stinfo/stcon/er/ec1/200609/P020 060904340916515023.rtf.

43 People's Daily, October 19, 2004, http://english. people.com.cn/200410/19/eng20041019_160673.html.

44 China Standards Consultation website: http://www. chinagb.org/2006/Article/news/hot/200611/10285.html. 45 And this is not only obstacle facing the developing countries. A survey found that $45 \%$ of US respondents had not converted to RoHS compliant parts, and $30 \%$ believe they are safe from complying with RoHS. The supply chain are facing more challenges from WEE, REACH besides many other environmental regulations.

46 China's RoHS is implemented in two phases: the 1st is administrative, with labeling and documentation requirements about the six hazardous substances in all electronic information products (EIP); and 2nd phase will work on the subset from the 1,800 specific parts listed by China's Ministry of Information Industry (MII).

47 The ISO tries to achieve balanced stakeholder participation for the first time in the standards development process by setting up a Working Group. ISO established special operating procedures for the WG, including a request that national member bodies participating in the work nominate a maximum of six experts, one for each of the six stakeholder categories: industry, government, labor, consumer, NGO, and other.

48 In Australia, the debate to reform Corporate Act to make it mandatory for directors to take into account stakeholder interests when making corporate decisions is still going on. In June 2006, the Parliament report concludes: "Companies are already subject to a range of Federal, Sate and Territory laws that are designed to protect various stakeholder groups or public values, including occupational health and safety, discrimination and equal opportunity in employment and the provision of goods and services, environmental impact and anticorruption laws. Each of these laws articulates minimum standards of conduct and enshrines certain rights in clear and accessible terms, with civil, and sometimes criminal, penalties associated with failure to adhere to the requisite standards" (CSR Report, Australian Government, Dec. 2006, p. 108). 


\section{Acknowledgements}

This study is part of the Research Project "Multilateral

Rules on Trade and Investment" supported by the SNF/NCCR Project "International Trade Regulation: From Fragmentation to Coherence", World Trade Institute (WTI), Berne.

\section{Appendix}

\section{APPENDIX A}

Overview of CSR rating institutions

\begin{tabular}{|c|c|c|}
\hline CSR rating institution & CSR issues & Main sources \\
\hline 100 Best corporate citizens & $\begin{array}{l}\text { Annual awards ceremony for companies } \\
\text { and SRI-Funds }\end{array}$ & http://www.business-ethics.com \\
\hline Accountability rating & $\begin{array}{l}\text { Social, ethical and environmental man- } \\
\text { agement }\end{array}$ & $\begin{array}{l}\text { http://www.accountabilityrating. } \\
\text { com }\end{array}$ \\
\hline ASSET4 & $\begin{array}{l}\text { Economic, environmental, social, and } \\
\text { corporate governance }\end{array}$ & http://www.asset4.com \\
\hline Covalence SA (ethical quote) & $\begin{array}{l}\text { Measuring reputation of multinational } \\
\text { enterprises on ethical issues }\end{array}$ & http://www.covalence.ch \\
\hline Ethinvest Environmental Index & $\begin{array}{l}\text { Environmental, social and Corporate } \\
\text { Governance performance }\end{array}$ & $\begin{array}{l}\text { http://www.corporatemonitor. } \\
\text { com.au }\end{array}$ \\
\hline $\begin{array}{l}\text { Johannesburg Securities Exchange } \\
\text { (JSE) SRI index }\end{array}$ & $\begin{array}{l}\text { How listed companies integrate the prin- } \\
\text { ciples of the Triple Bottom Line into their } \\
\text { business activities }\end{array}$ & Main source: http://www.jse.co.za \\
\hline FORTUNE 500 index & $\begin{array}{l}\text { FORTUNE } 500 \text { Index's objective is to } \\
\text { convert the reputation-index-criteria into } \\
\text { a capital market index. }\end{array}$ & $\begin{array}{l}\text { http://money.cnn.com/magazines/ } \\
\text { fortune/fortune } 500 /\end{array}$ \\
\hline $\begin{array}{l}\text { FTSE (Financial Times Stock Ex- } \\
\text { change) Group FTSE4Good }\end{array}$ & & $\begin{array}{l}\text { http://www.ftse.com, http:// } \\
\text { www.ftse4good.com }\end{array}$ \\
\hline $\begin{array}{l}\text { SIX/GES Ethical Index Global } \\
\text { Ethical Standards }\end{array}$ & $\begin{array}{l}\text { Based on international standards on the } \\
\text { environment, human rights and business } \\
\text { ethics, e.g., UN Global Compact, OECD } \\
\text { Guidelines for Multinational Enterprises, } \\
\text { ILO Core Labor Conventions. }\end{array}$ & http://www.ges-invest.com \\
\hline $\begin{array}{l}\text { Goldman Sachs Energy Environ- } \\
\text { mental and Social (GSEES) Index }\end{array}$ & Environmental and social issues & http://www.gs.com \\
\hline MAALA SRI Index & $\begin{array}{l}\text { Business Ethics, Workplace and Human } \\
\text { Rights, Community Investment and } \\
\text { Environment }\end{array}$ & http://www.maala.org.il \\
\hline NAI (Natur-Aktien-Index) & $\begin{array}{l}\text { Focused on topics like renewable energies } \\
\text { or consumer issues that are assessed by } \\
\text { using social, ethical and ecological criteria. }\end{array}$ & $\begin{array}{l}\text { http://www.natur-aktien-index.de, } \\
\text { http://www.securvita.de, } \\
\text { http://www.greeneffects.de }\end{array}$ \\
\hline
\end{tabular}




\section{APPENDIX A}

continued

\begin{tabular}{|c|c|c|}
\hline CSR rating institution & CSR issues & Main sources \\
\hline RepuTex SRI Index & $\begin{array}{l}\text { The index is independently calculated by } \\
\text { the international index provider Standard } \\
\text { \& Poor's on a daily basis. }\end{array}$ & http://www.reputex.com.au \\
\hline Social Index & Self assessment of the companies. & http://www.det.socialindeks.dk \\
\hline Westpac-Monash Eco-Index & Sustainable investing and ethical investing & $\begin{array}{l}\text { http://www.westpac.com.au, } \\
\text { http://www.monash.edu.au }\end{array}$ \\
\hline SERM Rating Agency Ltd. & $\begin{array}{l}\text { Environmental and social risk analysis in } \\
38 \text { sectors and } 500 \text { companies }\end{array}$ & http://www.serm.co.uk \\
\hline
\end{tabular}

Source: Bertelsmann Foundation (2006).

\section{APPENDIX B}

CSR-related legislative changes in developed countries

CSR mounting to national legislation agenda

Examples of Reform in Corporate Law for CSR disclosure

- The recently enacted UK Companies Act 2006 requires all companies other than small companies must produce a business review as part of the directors' report. For quoted companies, it is mandatory for their Review to include information about environmental matters, the company's employees and social and community issues, to the extent necessary for an understanding of the business. The review must also include financial key performance indicators (KPIs) and where appropriate, non-financial KPIs, including information relating to environmental and employee matters.

- Under the Australian legislation, ${ }^{48}$ companies are subject to CR disclosure. The Energy Efficiency Opportunities Act 2006 requires large energy-using private and public sector corporations to undertake assessments of their energy use and report publicly on the outcomes and their business responses.

- South Africa. Companies listed on the Johannesburg Stock Exchange (JSE) have been required since 2003 to report annually on their social and environmental performance using the Global Reporting Initiative (GRI) guidelines.

- Canada. Canadian companies are required to make annual financial statements and managements discussion and analysis (MD\&A). Financial statements must include the effect of any environmental exposures that materially impair the value of assets or created material obligations or contingent liabilities.

- EU: In May 2001, the EC issued a recommendation on the disclosure of environmental matters in the annual reports and accounts of EU companies. It noted that: "Investors need to know how companies deal with environmental issues. Regulatory authorities have an interest in monitoring the application of environmental regulations and the associated costs." (EU Commission Recommendation, 30 May 2001 (2001/453/EC)". The EU Accounts Modernization Directive (June 2003) expanded the reporting obligations of EU corporations beyond the financial to the environmental and social aspects of their operations.

- France and Belgium: require enterprises and subsidiaries located on their national territory to disclose statistical information on their workforce and its fluctuation, remuneration, health and safety, working conditions, training, labor relations, living conditions, and measures taken in favor of employment. France has also required since 2002, which all enterprises listed on the Premier Marché report on employee, community and environmental issues, how corporations' subsidiaries respect the ILO fundamental conventions and how these companies promote these conventions among their subcontractors.

- Denmark, the Netherlands, Norway and Sweden, have introduced mandatory requirements for environmental reporting for certain enterprises. Denmark mandated public environmental reporting in its "Green Accounting Law" in 1995, requiring over 3000 Danish companies to publish a "Green Account" describing their impact on the environment and the way in which they manage this impact. 


\section{APPENDIX B}

continued

- The United Kingdom Pensions Act of 1995 requires pension funds to disclose "the extent to which social, environmental or ethical considerations are taken into account in the selection, retention and realization of investments."

- Australia, Belgium, Germany and Sweden have introduced broadly similar legislation on socially responsible investment.

\section{References}

Bendady, D.: 2002, 'Check it out', Guardian, January 30. Blowfield, M.: 2000, 'Ethical Sourcing: A Contribution to Sustainability or a Diversion', Natural Resources and Ethical Trade Programme, NRI, March 2000.

Bowen, H.: 1953, Social Responsibilities of the Businessman (Harper \& Row, New York).

Brik, A. B.: 2007 'CSR Innovation: Its Antecedents and Impact on Market Orientation', Paper Presented at the AIB-UK Conference 2007, London.

Brunner, S. and D. Folly: 2007, 'The Way to a Multilateral Investment Agreement', NCCR Trade Regulation Working Paper, 24.

Chan, A. and J. S. Ross Robert: 2003, 'Racing to the Bottom: International Trade Without a Social Clause', Third World Quarterly 24(6), 1011-1028.

Chen, S. and B. Bouvain: 2007, 'A Comparison of Corporate Responsibility. Reporting in Three Countries: USA, Germany and Australia', Paper Presented at the AIB-UK Conference 2007, London.

Davies, R.: 2003, 'Social Responsibility and Corporate Values', in J. H. Dunning (ed.), Making Globalization Good: The Moral Challenges of Global Competition (Oxford University Press, UK), pp. 301-319.

Dowling, G. R.: 2001, Creating Corporate Reputations: Identity, Image and Performance (Oxford University Press, New York).

Dunning, J. H.: 2003, 'The Moral Imperatives of Global Capitalism: An Overview', in J. H. Dunning (ed.), Making Globalization Good: The Moral Challenges of Global Capitalism (Oxford University Press), pp. 11-40.

Economics Intelligence Unit (EIU): 2005, 'The Importance of Corporate Social Responsibility', A White Paper from the Economist Intelligence Unit Sponsored by Oracle, January.

ENHESA - Environmental Policy Center: 2003, 'ENHESA 2004 Global Forecast: Environmental, Health \& Safety Policy and Regulatory Developments Impacting Industry', Brussels and Washington.

Fombrun, C. J. and C. B. M. Van Riel: 2003, Fame E Fortune: How Successful Companies Build Winning
Reputations (Financial Times/Prentice Hall, Upper Saddle River, NJ).

Freeman, R. E.: 1984, Strategic Management: A stakeholder Approach (Pitman, Boston).

Goulbourne, T.: 2003, Corporate Social Responsibility: The Business Case (CIFP, Carleton University, Ottawa).

Gugler, P.: 2006, Towards a Coherent Multilateral Framework on FDI (Academy of International Business Insight).

Jamali, D.: 2007a, The Case of Corporate Social Responsibility for Developing Countries (Center for Business Ethics at Bentley College, Published by Blackwell Publishing, Malden, USA, and Oxford, UK).

Jamali, D.: 2007b, 'The Case for Strategic Corporate Social Responsibility in Developing Countries', Business and Society Review 112(1), 1-27.

Juholin, E.: 2004, 'For Business or the Good of All? A Finnish Approach to Corporate Social Responsibility', Corporate Governance 4(3), 20-21.

Kumar, R.: 2004, 'The State of CSR in India 2004', Background Paper for the National Seminar on Corporate Social Responsibility.

Kraisornsuthasinee, S. and F. W. Swierczek: 2006, 'Interpretation of CSR in Thai Companies', The Journal of Corporate Citizenship 22, 53-65.

Murillo, D. and J. M. Lozano: 2006, 'SMEs and CSR: An Approach to CSR I Their Own Words', Journal of Business Ethics 67, 227-240.

Pearce, B.: 2003, 'Sustainability and Business Competitiveness: Measuring the Benefit for Business Competitive Advantage from Social Responsibility and Sustainability', Forum for the Future.

Porter, M. E.: 1990, The Competitive Advantage of Nations (The Free Press, New York).

Porter, M. E.: 1998, On Competition (Harvard Business Review Book, Harvard Business School Press, Cambridge, MA, USA).

Porter, M. E., C. Ketels and M. Delgado: 2006, 'The Microeconomic Foundations of Prosperity: Findings from the Business Competitiveness Index', in A. Lopez-Claros, M. E. Porter, X. Sala-i-Martin and K. Schwab (eds.), Global Competitiveness Report 20062007 (Macmillan, Palgrave). 
Porter, M. E. and M. R. Kramer: 2003, 'The Competitive Advantage of Corporate Philanthropy', Harvard Business Review on Corporate Responsibility (Harvard Business School Publishing Corporation, Boston, MA), pp. 27-64.

Porter, M. E. and M. R. Kramer: 2006, 'Strategy and Society: The Link Between Competitive Advantage and Corporate Social Responsibility', Harvard Business Review.

Roberts, P. W. and G. R. Dowling: 2002, 'Corporate Reputation and Sustained Superior Financial Performance', Strategic Management Journal 23, 1077-1093.

Robertson, C. J., W. F. Crittenden, M. K. Brady and J. J. Hoffman: 2002, 'Situational Ethics Across Borders: A Multicultural Examination', Journal of Business Ethics July (12), 327-338.

Roman, R., S. Hayibor and B. B. Agle: 1999, 'The Relationship Between Social and Financial Performance', Business and Society 38(1), 109-125.

Twose, N. and T. Rao: 2003, 'Strengthening Developing Governments' Engagement with Corporate Social Responsibility: Conclusions and Recommendations from Technical Assistance in Vietnam', Final Report, World Bank's Program.

UNCTAD: 2006, 'Corporate Social Responsibility and TNCs from Developing and Transition Economies', World Investment Report 2006, pp. 232-246.

UNIDO: 2002, 'Corporate Social Responsibility: Implications for Small and Medium Enterprises in Develop- ing Countries', http://www.unido.org/userfiles/Beth keK/csr.pdf.

Wang, Y. and Y. R. Kang: 2002, Haier is Ocean (Haier Shi Hai) - the art of Management of Zhang Ruiming (Minzhu yu Jianshe Publishing, China).

World Economic Forum: 2006, 'The Global Competitiveness Report 2006-2007', Geneva, pp. 51-80.

Zedek, S.: 2002, 'Corporate Responsibility \& the Competitive Advantage of Nations', The Copenhagen Centre and AccountAbility.

Zhang, G. J.: 2006a, 'City View: Shenzhen's Efforts to Establish and Advance its CSR Policy', Business for Social Responsibility: Leading Perspectives Summer 11.

Zhang, K.: 2006b, 'China's Foreign Trade and Export Boom', From Book "China as the World Factory". New York.

Philippe Gugler and Jacylyn Y. J. Shi Faculty of Economics and Social Sciences, The University of Fribourg, Bd de Perolles 90, 1700 Fribourg, Switzerland E-mail: philippe.gugler@unifr.ch

World Trade Institute, Berne, Switzerland E-mail: jacylyn.shi@wti.org 